Kampus 4 Universitas Ahmad Dahlan Jl. Ringroad Selatan, Tamanan, Banguntapan, Bantul

Daerah Istimewa Yogyakarta 55191

Telp. : (0274) 563515 Fax. : (0274) 564604

e-mail : ihtifaz@uad.ac.id

Vol. 2, No. 1, Juni 2019, pp. 21-38

ISSN p:2622-4755 e:2622-4798.

DOI: https://doi.org/10.12928/ijiefb.v2i1.822

\title{
Kebijakan Spin-Off dan Efisiensi Perbankan Syariah di Indonesia
}

\section{Zulfikar Bagus Pambuko ${ }^{{ }^{*}}$}

${ }^{1}$ Program Studi Hukum Ekonomi Syariah, Universitas Muhammadiyah Magelang

*e-mail: zulfikar.bp@ummgl.ac.id 


\title{
Kebijakan Spin-Off dan Efisiensi Perbankan Syariah di Indonesia
}

\author{
Zulfikar Bagus Pambuko ${ }^{{ }^{*}}$ \\ ${ }^{1}$ Program Studi Hukum Ekonomi Syariah, \\ Universitas Muhammadiyah Magelang \\ *e-mail: zulfikar.bp@ummgl.ac.id
}

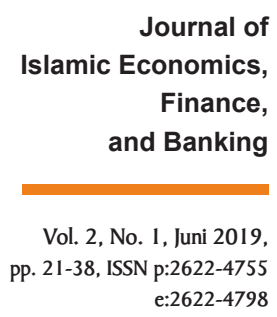

\begin{abstract}
The study aims to analyse the spin-off policies' impact on the Islamic banks' efficiency in Indonesia. The study was conducted on five spin-off Islamic banks and efficiency were measured by the BOPO ratio. The research variables used were dummy spin-off, ROA, FDR, and economic growth. Data analysis used panel data regression on annual data from 2008 to 2018. The results suggest that, first, the implementation of spin-off policy significantly increased the operational efficiency of Islamic banking. Second, ROA also has a negative effect on efficiency. Third, FDR and economic growth have no significant effect on the Islamic banks' efficiency in Indonesia.
\end{abstract}

Keywords: Spin-off, Efficiency, Islamic Bank

\begin{abstract}
Abstrak
Studi ini bertujuan untuk menganalisis dampak kebijakan spin-offterhadap efisiensi operasional bank syariah di Indonesia. Analisis dilakukan pada 5 bank syariah yang melakukan spin-off dan efisiensi diukur dengan rasio BOPO. Variabel penelitian yang digunakan adalah dummy spin-off, ROA, FDR, dan pertumbuhan ekonomi. Analisis data menggunakan teknik regresi data panel dengan data tahunan dari 2008 hingga 2018. Hasil penelitian menemukan bahwa, pertama, penerapan kebijakanspin-off secara signifikan meningkatkan efisiensi operasional perbankan syariah. Kedua, ROA juga terbukti berpengaruh negatif signifikan terhadap tingkat efisiensi. Ketiga, FDR dan pertumbuhan ekonomi tidak berpengaruh signifikan terhadap efisiensi perbankan syariah di Indonesia.
\end{abstract}

Kata Kunci: Spin-Off, Efisiensi, Bank Syariah

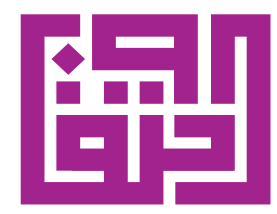




\section{PENDAHULUAN}

IHTIFAZ - JIEFB

Kesadaran menerapkan ajaran Islam secara menyeluruh (baca: kaffah) di seluruh aspek kehidupan, termasuk aspek keuangan mulai memperoleh respon sejak didirikan bank syariah pertama di Indonesia pada tahun 1991, yaitu Bank Muamalat. Lembaga Keuangan Syariah (LKS) lainnya juga mulai didirikan setelah itu. Regulator juga memberikan ruang bagi bank syariah untuk mengembangkan bisnisnya melalui Undang-undang nomor 7 tahun 1992 dengan pengakuan sebagai 'bank dengan prinsip bagi hasil'. Potensi masyarakat Muslim juga mendukung perkembangan bank syariah, utamanya setelah diterbitkan Undang-undang nomor 10 tahun 1998 yang menetapkan bahwa Indonesia menganut dual banking system, praktik konvensional dan syariah beroperasi beriringan. Akhirnya, pada tahun 2008, regulator menerbitkan aturan khusus bagi bank syariah melalui Undang-undang nomor 21 tahun 2008 yang kemudian menjadi cikal bakal pertumbuhan bank syariah (Pambuko, 2016; Pambuko, Ichsan, \& Anto, 2018). Salah satu isu krusial dalam UU tersebut adalah terkait kewajiban spin-offbagi unit usaha syariah.

Setelah disahkan UU 21 tahun 2008 tentang Perbankan syariah, telah dilakukan 11 spin-offdengan berbagai metode, diantaranya pemisahan murni, konversi, akuisisi, dan lain sebagainya (Al Arif, 2015a; Al Arif \& Dewanti, 2017; Hilman, 2018). Tabel 1 di bawah ini menjelaskan bahwa sebelum UU diterapkan, hanya ada 3 Bank Umum Syariah (BUS) dan 26 Unit Usaha Syariah (UUS) yang kemudian terus bertambah dimana puncaknya terjadi pada tahun 2010. Pada tahun tersebut, 5 BUS baru yang merupakan produk kebijakan spin-off telah didirikan dan menjadikan jumlah bank syariah menjadi 11 BUS, 23 UUS, dan 150 BPRS. Dari aspek kelembagaan, jumlah tersebut terus berkembang dimana pada Desember 2018 terdapat 14 BUS, 20 UUS, dan 167 BPRS yang memiliki 2,724 jaringan kantor di seluruh Indonesia dan menyerap 59,389 tenaga kerja. Kondisi ini membuktikan eksistensi dan kontribusi bank syariah di industri keuangan Nasional. Namun demikian, kebijakan spin-off ini masih membutuhkan evaluasi lanjutan (Al Arif, Nachrowi, Nasution, \& Mahmud, 2017; Haribowo, 2017). 
Tabel 1. Perkembangan Jumlah Bank Syariah di Indonesia

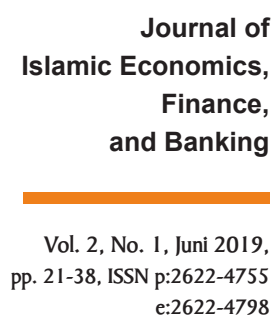

\begin{tabular}{cccc}
\hline Tahun & BUS & UUS & BPRS \\
\hline 2007 & 3 & 26 & 114 \\
2008 & 5 & 27 & 131 \\
2009 & 6 & 25 & 138 \\
2010 & 11 & 23 & 150 \\
2011 & 11 & 24 & 155 \\
2012 & 11 & 24 & 158 \\
2013 & 11 & 23 & 163 \\
2014 & 12 & 22 & 163 \\
2015 & 12 & 22 & 163 \\
2016 & 13 & 21 & 166 \\
2017 & 13 & 21 & 167 \\
2018 & 14 & 20 & 167 \\
\hline
\end{tabular}

$22-4798$

Sumber: OJK (2018)

Ditinjau dari aspek keuangan, kinerja bank syariah terus mengalami fluktuasi dimana pada tahun 2008 hingga 2013 terjadi pertumbuhan yang relatif pesat, namun menurun mulai tahun 2014 hingga 2017. Tabel 2 di bawah ini menunjukkan bahwa payung hukum tentang perbankan syariah berdampak pada aspek profitabilitas dimana rasio ROA terus mengalami peningkatan hingga tahun 2013. Hal ini juga terjadi pada jumlah pembiayaan bermasalah (NPF) dan efisiensi operasional (BOPO) yang terus mengalami perbaikan kinerja hingga tahun 2013. Namun demikian, 4 periode setelahnya dari 2014 hingga 2017, bank syariah mengalami stagnasi dimana kinerja keuangan tidak mengalami perkembangan yang signifikan. Di sisi lain, pada akhir tahun 2018 lalu, bank syariah di Indonesia telah menunjukkan gairahnya dimana seluruh kinerja keuangannya mengalami peningkatan dari tahun sebelumnya. Secara khusus, menilik perkembangan market share bank syariah, kebijakan spin-off menjadi salah satu solusi dalam pemenuhan target penguasaan pasar (Al Arif, 2017). Purwanto (2018) menambahkan bahwa konversi Bank Aceh Syariah membuat target pangsa pasar 5\% tercapai pada akhir tahun 2016. 
Tabel 2. Kinerja Keuangan Bank Syariah di Indonesia

\begin{tabular}{cccccccc}
\cline { 2 - 7 } IHTIFAZ - JIEFB & Tahun & CAR & ROA & NPF & FDR & BOPO & $\begin{array}{c}\text { Market } \\
\text { Share }\end{array}$ \\
\cline { 2 - 7 } & 2008 & 12.81 & 1.42 & 1.42 & 103.65 & 81.75 & 2.1 \\
& 2009 & 10.77 & 1.48 & 4.01 & 89.70 & 84.39 & 2.61 \\
2010 & 16.25 & 1.67 & 3.02 & 89.67 & 80.54 & 3.24 \\
2011 & 16.63 & 1.90 & 2.52 & 88.94 & 78.41 & 3.98 \\
2012 & 14.13 & 2.14 & 2.22 & 100.00 & 74.97 & 4.58 \\
2013 & 14.42 & 2.00 & 2.62 & 100.32 & 78.21 & 4.89 \\
2014 & 15.74 & 0.41 & 4.95 & 86.66 & 96.97 & 4.85 \\
2015 & 15.02 & 0.49 & 4.84 & 88.03 & 97.01 & 4.83 \\
2016 & 16.63 & 0.63 & 4.42 & 85.99 & 96.22 & 5.3 \\
& 2017 & 17.91 & 0.63 & 4.76 & 79.61 & 94.91 & 5.78 \\
2018 & 20.39 & 1.28 & 3.26 & 78.53 & 89.18 & 5.92 \\
\hline
\end{tabular}

Sumber: OJK (2018)

Fenomena kebijakan spin-off ini telah menjadi perhatian banyak penelitian dalam beberapa tahun terakhir. Beberapa temuan cenderung mengarahkan bahwa kebijakan tersebut membutuhkan peninjauan ulang. Kebijakan spin-off tidak berpengaruh terhadap pertumbuhan pembiayaan, pertumbuhan aset, dan profitabilitas (Al Arif, 2015a, 2015c; Al Arif \& Dewanti, 2017; Sihombing \& Yahya, 2016). Kebijakan spinoffjuga menurunkan pangsa pasar perbankan syariah (Al Arif, 2017). Lain daripada itu, kebijakan spin-off mampu meningkatkan jumlah DPK (AI Arif, 2014, 2018). Bagi bank konvensional, kebijakan spin-off berdampak negatif terhadap kinerja dengan penurunan profit dan peningkatan inefisiensi (Poerwokoesoemo, 2016). Di sisi lain, Hamid (2015) memiliki temuan yang berbeda dimana kebijakan spin-off berpengaruh terhadap profitabilitas perbankan syariah.

Pada konteks efisiensi, analisis lebih lanjut dibutuhkan untuk menjamin bahwa perbankan syariah mampu bertahan di tengah lingkungan yang semakin kompetitif (Firdaus \& Hosen, 2013). Terlebih bank syariah saat ini belum mampu beroperasi secara efisien, baik dalam pengelolaan dana finansial maupun dana sosial (Endri, 2008; Firdaus \& Hosen, 2013; Lutfiana \& Yulianto, 2015; Pambuko, 2016; Putra, Syifadhiya, Widyastiti, \& Pambuko, 2018). Bank syariah akan semakin efisien setelah melakukan spin-off (Sarifudin \& Faturohman, 2017). Namun di sisi lain, beberapa studi menemukan hasil berbeda dimana keputusan spin-off membuat bank menjadi semakin tidak efisien (Al Arif, 2015b; Al Arif, Haribowo, \& Suherlan, 2018; Poerwokoesoemo, 2016). FDR dan ROA yang semakin besar serta NPF yang semakin rendah akan mendorong bank semakin efisien (Firdaus \& Hosen, 2013; Shidiqi \& Rachmawati, 2018; Sufian, 2009; Sufian \& Noor, 2009). Lebih lanjut, pertumbuhan ekonomi juga mendorong bank syariah menjadi semakin efisien (Ahmad \& Noor, 2010; Akhtar, 2013; Sufian \& Noor, 2009). 
Berdasarkan seluruh uraian di atas, studi ini diarahkan untuk menganalisis dampak kebijakan spin-off terhadap tingkat efisiensi perbankan syariah di Indonesia. Lebih lanjut, beberapa faktor determinan juga diuji pengaruhnya terhadap tingkat efisiensi. Studi ini dapat berkontribusi pada pengambilan kebijakan bagi bank induk konvensional sebelum melakukan spin-off. Hal ini menjadi penting karena kebijakan ini adalah kekhasan yang dimiliki Indonesia dan memungkinkan untuk diaplikasikan di Negara lain.

\section{TINJAUAN PUSTAKA}

Studi tentang dampak kebijakan spin-off terhadap efisiensi tidaklah berdiri sendiri sebagai riset yang terpisah, namun merupakan pengembangan dari studi-studi yang telah dilakukan sebelumnya. Peneliti secara pribadi telah beberapa kali melakukan kajian efisiensi pada perbankan syariah, diantaranya determinan efisiensi dengan pendekatan two-stages DEA (Pambuko, 2016) dan efisiensi pengelolaan dana sosial (Putra et al., 2018). Lebih lanjut, riset yang berkaitan dengan kebijakan spin-off juga pernah dilakukan, yaitu berkaitan dengan dampak kebijakan spin-off terhadap produktivitas pengelolaan dana sosial di perbankan syariah (Pambuko, Usman, \& Andriyani, 2019). Namun demikian, banyak studi-studi lain yang berkaitan dengan kajian efisiensi di bank syariah.

Firdaus \& Hosen (2013) melakukan studi tentang tingkat efisiensi Bank Umum Syariah (BUS), analisis determinan efisiensi BUS, dan perbandingan metode pengukuran efisiensi antara DEA dengan CAELS. Studi dilakukan dengan data kuartal dari Q2 2010 hingga Q4 2012. Studi ini menemukan bahwa bank syariah selama periode observasi belum mampu mencapai tingkat efisiensi yang optimum. Variabel penelitian yang terbukti mampu meningkatkan efisiensi bank syariah adalah aset, ROA, ROE, dan NPF. Sedangkan jumlah cabang dan CAR berpengaruh negatif terhadap tingkat efisiensi bank syariah.

Al Arif (2015) melakukan studi tentang keterkaitan kebijakan pemisahan terhadap tingkat efisiensi pada industri perbankan syariah di Indonesia. Data yang digunakan adalah data bulanan industri perbankan syariah dari tahun 2006 hingga 2014. Efisiensi diukur dengan rasio BOPO. Penelitian ini menemukan bahwa kebijakan pemisahan berpengaruh positif signifikan terhadap efisiensi, sedangkan marjin deposito 1 bulan dan ROA berpengaruh negatif signifikan terhadap efisiensi. Lebih lanjut, DPK, pembiayaan, total aset, dan NPF tidak berpengaruh signifikan terhadap efisiensi perbankan syariah.

Lutfiana \& Yulianto (2015) melakukan studi tentang analisis efisiensi Bank Umum Syariah dan faktor yang mempengaruhinya dengan pendekatan two-stages DEA. Studi pada 8 BUS dengan data kuartal dari Q1 2011 hingga Q3 2014 menemukan bahwa CAR berpengaruh positif signifikan terhadap tingkat efisiensi dan BOPO berpengaruh negatif 
signifikan. Sedangkan ROE, NPF, PPAP, FDR, dan cabang bank tidak berpengaruh signifikan terhadap tingkat efisiensi.

Pambuko (2016) melakukan studi tentang analisis efisiensi bank syariah dan faktor yang mempengaruhinya dengan pendekatan twostages DEA. Studi pada 11 BUS pada 2010-2013 dengan data tahunan menemukan bahwa CAR, ROA, NPF, FDR, NIM berpengaruh positif signifikan terhadap efisiensi perbankan syariah. GCG berpengaruh negatif signifikan, sedangkan GDP dan inflasi tidak berpengaruh signifikan.

Sarifudin \& Faturohman (2017) melakukan studi dampak spin-off terhadap efisiensi 4 bank syariah yang melakukan spin-off. Sampel yang digunakan adalah BRI Syariah, BNI Syariah, Bank Bukopin Syariah, dan Bank Jabar dan Banten Syariah. Studi ini menggunakan data triwulanan dari tahun 2004-2013. Studi ini menemukan bahwa BRIS, BNIS, dan BJBS efisiensinya meningkat setelah spin-off, sedangkan BSB menurun efisiensinya. Pengujian kedua menggunakan uji MannWhitney menemukan bahwa pada BRI Syariah dan BNI Syariah tidak ada perbedaan signifikan sebelum dan sesudah spin-off, sedangkan BJBS dan BSB ada perbedaan signifikan.

Al Arif et al., (2018) melakukan studi tentang dampak spin-off terhadap efisiensi bank syariah di Indonesia. Analisis data menggunakan teknik difference in differences analysis dengan data triwulanan 20052015 dengan 4 bank syariah sebagai sampel, yaitu BRIS, BNIS, Bukopin, dan BJBS. Efisiensi diukur dengan BOPO. Studi ini menemukan bahwa kebijakan spin-off berpengaruh signifikan terhadap efisiensi bank syariah dimana terjadi penurunan efisiensi setelah spin-off. Kemudian inflasi dan dana pihak ketiga berpengaruh positif signifikan terhadap BOPO serta pembiayaan berpengaruh negatif signifikan terhadap BOPO. Adapun variabel suku bunga dan pertumbuhan ekonomi tidak berpengaruh signifikan terhadap efisiensi (BOPO).

Shidiqi \& Rachmawati (2018) melakukan studi tentang faktor yang mempengaruhi efisiensi perbankan syariah di Indonesia. Efisiensi diukur dengan BOPO pada 11 BUS pada 2012-2016 dan dianalisis dengan regresi data panel. Hasil studi ini menemukan bahwa ROA, FDR, dan jumlah kantor cabang berpengaruh negatif signifikan terhadap efisiensi (BOPO). Rasio NPF berpengaruh positif signifikan serta rasio CAR dan ROE tidak berpengaruh signifikan terhadap efisiensi perbankan syariah di Indonesia.

Berdasarkan seluruh pemaparan di atas, studi ini akan mengembangkan studi Al Arif et al., (2018) dengan menambahkan bank syariah spin-off baru yang menjadi objek studi, yaitu Bank Aceh Syariah. Lebih lanjut, variabel, data penelitian, dan metode analisis yang digunakan juga telah dikembangkan sesuai dengan kebutuhan studi ini. 


\section{METODE PENELITIAN}

Penelitian ini menganalisis pengaruh kebijakan spin-off terhadap tingkat efisiensi perbankan syariah di Indonesia. Selain itu, penelitian ini juga memasukkan variabel Return on Asset (ROA), Financing to Deposit Ratio (FDR), dan pertumbuhan ekonomi yang akan diuji pengaruhnya terhadap tingkat efisiensi. Objek kajian pada studi ini adalah lima bank syariah yang telah melakukan pemisahan (spin-off), yaitu Bank Syariah Bukopin (BSB), BRI Syariah (BRIS), Bank Jabar dan Banten Syariah (BJBS), BNI Syariah (BNIS), dan Bank Aceh Syariah (BAS). Penggunaan kelima bank syariah didasarkan pada keterbatasan data yang dapat diakses oleh peneliti.

Data yang digunakan adalah data sekunder yang berbentuk data panel yang dikumpulkan dari berbagai sumber yang relevan, diantaranya BPS, Bank Indonesia, OJK, dan annual report masing-masing bank syariah. Data yang terkumpul merupakan data tahunan mulai tahun 2008 hingga 2018.

Penelitian ini menggunakan 1 variabel dependen dan 4 variabel independen. Variabel dependennya adalah efisiensi yang diproksikan dengan rasio Biaya Operasional terhadap Pendapatan Operasional (BOPO). Semakin tinggi nominal rasio BOPO, maka bank syariah semakin tidak efisien. Variabel independen yang digunakan adalah penelitian ini adalah dummy spin-off, Return on Asset (ROA), Financing to Deposit Ratio (FDR), dan pertumbuhan ekonomi.

a. Dummy spin-off merupakan variabel dummy dimana periode sebelum spin-off dinotasikan dengan ' 0 ' dan periode setelah spin-off dinotasikan dengan ' 1 '.

b. Return on Asset (ROA) mencerminkan besarnya pendapatan bersih bank syariah dibandingkan dengan total asset dan disajikan dalam bentuk persentase (\%).

c. Financing to Deposit Ratio (FDR) mencerminkan besarnya alokasi pembiayaan dari dana dana pihak ketiga dan disajikan dalam bentuk persentase (\%)

d. Pertumbuhan ekonomi diukur menggunakan proksi Industrial Production Index (IPI) atas harga tahun dasar 2010 dan disajikan dalam bentuk indeks.

Guna menjawab tujuan penelitian, studi menggunakan analisis regresi data panel. Data panel ini merupakan penggabungan antara data cross section dengan time series yang menghasilkan tiga hasil estimasi, yaitu Pooled Least Square (PLS), Fixed Effect Model (FEM), dan Random Effect Model (REM). Analisis data diawali dengan pengujian kesesuaian model atau model terbaik dan dilanjutkan dengan interpretasi model estimasi terbaik (Nuryanto \& Pambuko, 2018). Persamaan matematis untuk penelitian ini adalah sebagai berikut:

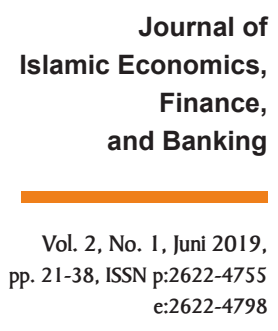

Journal of

Islamic Economics,

Finance,

and Banking

Vol. 2, No. 1, Juni 2019 , pp. 21-38, ISSN p:2622-4755 e:2622-4798 


$$
\mathrm{BOPO}_{\mathrm{it}}=\mathrm{a}+\beta_{1} \mathrm{D}_{\mathrm{it}}+\beta_{2} \mathrm{ROA}_{\mathrm{it}}+\beta_{3} \mathrm{FDR}_{\mathrm{it}}+\beta_{4} \mathrm{IPI}_{\mathrm{it}}+\varepsilon_{\mathrm{it}}
$$

IHTIFAZ - JIEFB

Keterangan:

$$
\begin{array}{ll}
\text { BOPO } & =\text { efisiensi } \\
\text { D } & =\text { dummy spin-off dimana } 0=\text { sebelum spin-off dan } \\
& 1=\text { setelah } \text { spin-off } \\
\text { ROA } & =\text { return on asset } \\
\text { FDR } & =\text { financing to deposit ratio } \\
\text { IPI } & =\text { pertumbuhan ekonomi Indonesia }
\end{array}
$$

\section{HASIL PENELITIAN DAN PEMBAHASAN}

\section{Analisis Deskriptif}

Hasil analisis deskriptif di bawah ini menyajikan ringkasan kondisi masing-masing bank syariah yang menjadi objek penelitian berdasarkan kinerja keuangan sepanjang periode observasi. Hasil analisis deskriptif tersebut berupa data nilai minimal, nilai maksimal, nilai rata-rata, dan standar deviasi. Berikut ini disajikan hasil analisis deskriptif secara lengkap.

Tabel 3. Analisis Deskriptif Variabel Penelitian

\begin{tabular}{lrrrr}
\hline \multicolumn{1}{c}{ Variabel } & \multicolumn{1}{c}{ Min } & \multicolumn{1}{c}{ Max } & \multicolumn{1}{c}{ Mean } & \multicolumn{1}{c}{ Std. Dev } \\
\hline BOPO_BAS & 70.57 & 94.43 & 77.77 & 8.46 \\
BOPO_BJBS & 64.92 & 134.63 & 95.29 & 21.51 \\
BOPO_BNIS & 83.94 & 135.10 & 92.15 & 14.44 \\
BOPO_BRIS & 86.63 & 215.58 & 106.25 & 36.47 \\
BOPO_BSB & 91.59 & 187.84 & 103.24 & 28.22 \\
ROA_BAS & 0.52 & 3.66 & 2.67 & 0.88 \\
ROA_BJBS & -8.09 & 3.16 & -0.34 & 3.47 \\
ROA_BNIS & -3.60 & 1.48 & 0.81 & 1.49 \\
ROA_BRIS & -2.52 & 1.19 & 0.33 & 1.01 \\
ROA_BSB & -1.14 & 0.79 & 0.30 & 0.57 \\
FDR_BAS & 39.05 & 92.38 & 77.44 & 16.04 \\
FDR_BJBS & 79.61 & 205.42 & 107.69 & 34.57 \\
FDR_BNIS & 68.92 & 102.98 & 85.50 & 9.94 \\
FDR_BRIS & 71.87 & 184.37 & 100.20 & 31.14 \\
FDR_BSB & 82.44 & 100.62 & 91.64 & 6.52 \\
IPI & 93.10 & 145.04 & 117.37 & 17.45 \\
\hline
\end{tabular}

Sumber: Data diolah (2019) 
Tabel 3 di atas menunjukkan kondisi rasio keuangan bank syariah yang menerapkan kebijakan spin-off dari unit usaha syariah menjadi bank umum syariah. Selama 11 tahun terakhir, kinerja keuangan dari kelima bank syariah juga tidak identik. Pertama, rasio BOPO yang menjadi proksi dari tingkat efisiensi diketahui bahwa Bank Aceh Syariah adalah bank syariah yang paling efisien dibandingkan 4 bank syariah lainnya. Hal ini dapat diketahui dari nilai rata-rata BOPO selama 11 tahun adalah sebesar $77.77 \%$ dengan rasio tertinggi sebesar $94.43 \%$ dan terendah $70.57 \%$. Sedangkan bank syariah yang belum mampu beroperasi secara efisien adalah BRI Syariah dan Bank Syariah Bukopin dengan rata-rata BOPO sebesar 106.25\% dan 103.24\%.

Kedua, rasio Retur non Aset (ROA) yang mencerminkan kemampuan bank syariah dalam menghasilkan keuntungan dengan menggunakan aset yang dimiliki juga mengunggulkan Bank Aceh Syariah sebagai bank syariah yang paling profitable (menguntungkan) dengan rata-rata ROA sebesar 2.67\%. Lebih lanjut, 3 bank syariah lainnya, yaitu BNI Syariah, BRI Syariah, dan Bank Syariah Bukopin juga memiliki rasio ROA yang positif meskipun beberapa periode mengalami fluktuasi dengan rasio ROA yang negatif. Adapun Bank Jabar dan Banten Syariah dalam 11 tahun terakhir menghasilkan keuntungan yang fluktuatif dan secara rata-rata bernilai negatif sebesar $-0.34 \%$ dengan rasio tertinggi sebesar $3.16 \%$ dan terendah sebesar $-8.09 \%$.

Ketiga, rasio Financing to Deposit Rasio (FDR) yang mencerminkan besaran pembiayaan yang disalurkan dari Dana Pihak Ketiga (DPK) menempatkan Bank Jabar dan Banten Syariah sebagai bank syariah yang paling besar menyalurkan pembiayaan sebesar $107.69 \%$ dengan rasio tertinggi sebesar $205.42 \%$ dan terendah sebesar $79.61 \%$. Peringkat kedua diduduki oleh BRI Syariah dengan rata-rata FDR sebesar $100.2 \%$. Sedangkan bagi tiga bank syariah lainnya, rata-rata FDR berada pada batas normal yang ditetapkan oleh OJK dimana GWM-FDR maksimal sebesar $92 \%$.

Keempat, variabel pertumbuhan ekonomi yang diproksikan dengan Industrial Production Index (IPI) memiliki nilai rata-rata sebesar 117.37 dengan standar deviasi sebesar 17.45. Hal ini menunjukkan sebaran data normal dan tidak ada yang menyimpang. Indeks terendah adalah sebesar 93.10 dan tertinggi sebesar 145.04.

\section{Uji Kesesuaian Model}

Uji kesesuaian model dilakukan dalam tiga tahapan pengujian, yaitu Langrange Multiplier (LM) test, Chow test, dan Hausman test. LM test dilakukan untuk memutuskan model terbaik antara PLS dan FEM. Chow test untuk memutuskan model terbaik antara PLS dan REM. Hausman test untuk memutuskan model terbaik antara FEM dan REM. Tabel 4 dan 5 menunjukkan hasil dari ketiga pengujian tersebut. 
Tabel 4. Hasil Chow test dan LM test

IHTIFAZ - JIEFB

Redundant Fixed Effects Tests

Test cross-section fixed effects

\begin{tabular}{lrrr}
\hline Effects Test & Statistic & d.f. & Prob. \\
Cross-section F & 2.761672 & $(4,46)$ & 0.0386 \\
Cross-section Chi-square & 11.837574 & 4 & 0.0186 \\
\hline
\end{tabular}

Sumber: Data diolah (2019)

Berdasarkan tabel 4 di atas, diketahui bahwa nilai prob. cross-section $F$ yang digunakan dalam chow test adalah 0.0386 yang lebih kecil dari 0.05. Dengan demikian, hipotesis alternatif diterima dan hipotesis awal ditolak. Artinya, model PLS ditolak dan Fixed Effect Model (FEM) diterima. Kemudian, nilai prob. cross-section chi-square yang digunakan dalam LM test adalah 0.0186 yang lebih kecil dari 0.05. Dengan demikian, hipotesis alternatif diterima dan hipotesis awal ditolak. Artinya, model PLS ditolak dan Random Effect Model (REM) diterima.

Kedua hasil pengujian di atas menyimpulkan bahwa model Pooled Least Square (PLS) ditolak, sedangkan FEM dan REM diterima. Dengan demikian perlu dilakukan pengujian selanjutnya yang disebut dengan hausman test.

Tabel 5. Hasil Hausman test

\section{Correlated Random Effects - Hausman Test}

Test cross-section random effects

\begin{tabular}{lrrr}
\hline Test Summary & $\begin{array}{r}\text { Chi-Sq. } \\
\text { Statistic }\end{array}$ & Chi-Sq. d.f. & Prob. \\
Cross-section random & 8.408853 & 4 & 0.0777 \\
\hline
\end{tabular}

Sumber: Data diolah (2019)

Berdasarkan tabel 5 di atas, diketahui bahwa nilai prob. Crosssection random yang digunakan dalam hausman test adalah 0.0777 yang lebih besar dari 0.05 . Dengan demikian, hipotesis alternatif ditolak dan hipotesis awal diterima. Artinya, model REM diterima dan FEM ditolak. Berdasarkan ketiga hasil pengujian kesesuaian model, dapat disimpulkan bahwa model terbaik yang digunakan adalah Random Effect Model (REM). 


\section{Uji Hipotesis}

Berdasarkan hasil uji kesesuaian model, model terbaik yang digunakan untuk menganalisis dampak kebijakan spin-off terhadap tingkat efisiensi perbankan syariah di Indonesia adalah Random Effect Model (REM). REM ini juga dikenal dengan teknik Generalized Least Square (GLS).

Berdasarkan tabel 6 diketahui bahwa dua variabel terbukti memiliki pengaruh yang signifikan terhadap tingkat efisiensi perbankan syariah. Sedangkan dua variabel lainnya tidak memiliki pengaruh yang signifikan. Berikut ini adalah penjabaran dari masing-masing variabel yang diamati.

Pertama, nilai prob. variabel spin-off adalah 0.0498 yang lebih kecil dari 0.05 yang menunjukkan bahwa hipotesis alternatif diterima. Artinya variabel spin-off memiliki pengaruh yang signifikan terhadap tingkat efisiensi perbankan syariah di Indonesia. Kemudian, nilai koefisien regresi variabel spin-off sebesar -12.17048 yang bertanda negatif menunjukkan bahwa jika kebijakan spin-off diterapkan, maka rasio BOPO akan semakin kecil. Dengan demikian, ketika kebijakan spin-off diterapkan, maka bank syariah akan semakin efisien dari operasionalnya.

Kedua, nilai prob. variabel Return on Asset (ROA) adalah 0.0000 yang lebih kecil dari 0.05 yang menunjukkan bahwa hipotesis alternatif diterima. Artinya variabel ROA memiliki pengaruh yang signifikan terhadap tingkat efisiensi perbankan syariah di Indonesia. Kemudian, nilai koefisien regresi variabel ROA sebesar -9.224402 yang bertanda negatif menunjukkan bahwa jika ROA meningkat, maka rasio BOPO akan semakin kecil. Dengan demikian, ketika kemampuan bank syariah dalam menghasilkan keuntungan dari asset yang dikuasai semakin baik, maka bank syariah akan beroperasi lebih efisien.

Ketiga, nilai prob. Variabel Financing to Deposit Ratio (FDR) adalah 0.1016 yang lebih besar dari 0.05 yang menunjukkan bahwa hipotesis awal diterima. Artinya variabel FDR tidak memiliki pengaruh yang signifikan terhadap tingkat efisiensi. Kemudian, nilai koefisien regresi variabel FDR sebesar 0.158557 yang bertanda positif menunjukkan bahwa jika FDR meningkat, maka rasio BOPO akan semakin besar.

Keempat, nilai prob. variabel pertumbuhan ekonomi (IPI) adalah 0.5394 yang lebih besar dari 0.05 yang menunjukkan bahwa hipotesis awal diterima. Artinya pertumbuhan ekonomi tidak memiliki pengaruh yang signifikan terhadap tingkat efisiensi bank syariah. Kemudian, nilai koefisien regresi variabel IPI sebesar -0.095510 yang bertanda negatif menunjukkan bahwa jika IPI meningkat, maka rasio BOPO akan semakin kecil.

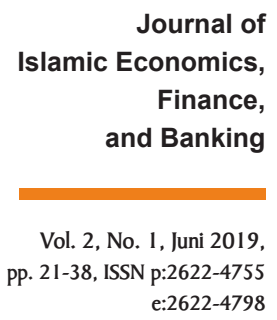


Tabel 6. Hasil Regresi Data Panel REM

IHTIFAZ - JIEFB

\begin{tabular}{crrrr}
\hline Variable & Coefficient & Std. Error & t-Statistic & Prob. \\
\hline C & 107.5184 & 21.18856 & 5.074363 & 0.0000 \\
SPIN_OFF? & -12.17048 & 6.054054 & -2.010302 & 0.0498 \\
ROA? & -9.224402 & 1.137366 & -8.110323 & 0.0000 \\
FDR? & 0.158557 & 0.096355 & 1.645556 & 0.1061 \\
IPI? & -0.095510 & 0.154553 & -0.617973 & 0.5394
\end{tabular}

Random Effects

(Cross)

$\begin{array}{cc}\text { _BSB--C } & 0.980916 \\ \text { _BRIS--C } & 1.289325 \\ \text { _BNIS--C } & -0.043576 \\ \text { _BJBS--C } & -1.780161 \\ \text { _BAS--C } & -0.446505\end{array}$

Effects Specification

S.D. Rho

Cross-section random

$2.075346 \quad 0.0168$

Idiosyncratic random

$15.89912 \quad 0.9832$

Weighted Statistics

R-squared

0.579555 Mean dependent var

87.12503

Adjusted

R-squared

0.545920 S.D. dependent var 24.83770

S.E. of regression

16.73700 Sum squared resid

14006.37

F-statistic

17.23042 Durbin-Watson stat

1.149453

Prob(F-statistic)

0.000000

Unweighted Statistics

R-squared

0.578000 Mean dependent var

94.93930

Sum squared resid

14424.14

Durbin-Watson stat

1.116161

Sumber: Data diolah (2019)

\section{Pembahasan}

Kajian tentang dampak kebijakan spin-off yang dilaksanakan oleh bank syariah sesuai amanah Undang-undang nomor 21 tahun 2008 tentang Perbankan Syariah terhadap tingkat efisiensi perbankan syariah di Indonesia dilakukan dengan analisis regresi data panel pada periode 2008-2018. Selain menguji dampak kebijakan spin-off, studi ini juga menganalisis pengaruh ROA, FDR, dan pertumbuhan ekonomi terhadap 
tingkat efisiensi perbankan syariah.

Spin-off merupakan keniscayaan yang harus dilakukan oleh setiap unit usaha syariah di Indonesia. Kewajiban ini merujuk pada Undangundang nomor 21 tahun 2008 tentang Perbankan Syariah. Spin-off harus dilakukan ketika aset unit syariah telah mencapai $50 \%$ dari bank induknya atau lima belas tahun setelah UU berlaku, yaitu tahun 2023 (RI, 2008). Setelah kebijakan tersebut, 10 Unit Usaha Syariah (UUS) melakukan spin-off meskipun syarat yang telah ditetapkan belum terpenuhi dengan berbagai skenario spin-off yang tersedia (Pambuko et al., 2019). Dengan demikian, jumlah Bank Umum Syariah (BUS) bertambah pesat dimana sebelum kebijakan hanya ada 3 BUS dan di akhir tahun 2018 menjadi 14 BUS.

Berdasarkan hasil analisis pada tabel 6, kebijakan spin-off terbukti mampu memberikan kontribusi signifikan bagi pencapaian efisiensi perbankan syariah. Secara statistik dijelaskan bahwa ketika keputusan spin-off diambil oleh bank syariah, maka rasio BOPO akan menurun yang menunjukkan terjadinya peningkatan efisiensi operasional. Efisiensi ini diperoleh dari semakin rendahnya porsi pendapatan operasional yang digunakan untuk membiayai kegiatan operasional (beban) perbankan. Temuan ini mendukung studi Sarifudin \& Faturohman (2017) yang mengungkapkan bahwa setelah spin-off, tidak efisiensi bank syariah semakin baik. Namun demikian, studi Al Arif (2015b), Al Arif, Haribowo, \& Suherlan (2018), dan Poerwokoesoemo (2016) mengungkapkan bahwa keputusan spin-off membuat bank menjadi semakin tidak efisien. Perbedaan hasil ini dimungkinkan disebabkan oleh perbedaan objek dan periode observasi yang digunakan oleh masing-masing peneliti.

Kemampuan bank syariah dalam menghasilkan keuntungan dari aset yang dikuasai melalui ROA juga terbukti memberikan kontribusi signifikan terhadap tingkat efisiensi perbankan syariah. Bank syariah akan semakin efisien operasionalnya ketika mampu menghasilkan keuntungan lebih besar. Temuan ini mendukung studi Al Arif (2015b), Firdaus \& Hosen (2013), Pambuko (2016), Shidiqi \& Rachmawati (2018), dan Sufian \& Noor (2009) yang menyatakan bahwa ROA mendorong efisiensi perbankan syariah.

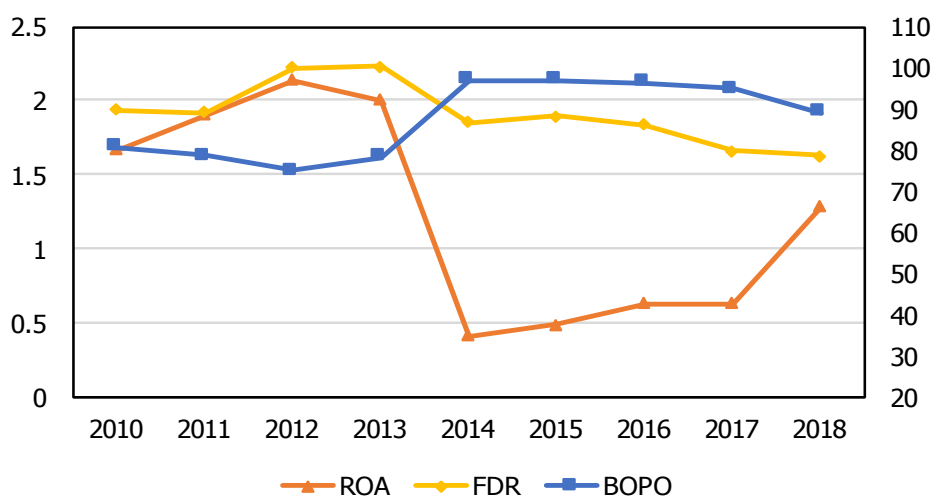

Gambar 1. Interaksi BOPO, ROA, dan FDR Perbankan Syariah di Indonesia 
FDR terbukti tidak mampu memberikan kontribusi dalam pencapaian efisiensi bagi bank syariah. Banyak atau sedikitnya jumlah pembiayaan yang disalurkan oleh perbankan tidak mempengaruhi tingkat efisiensi. Hasil ini tidak mendukung temuan Al Arif et al. (2018), Pambuko (2016), Shidiqi \& Rachmawati (2018), Sufian (2009), dan Sufian \& Noor (2009) yang menyatakan bahwa bank akan semakin efisien ketika mampu menyalurkan lebih banyak pembiayaan. Namun demikian, studi ini mendukung temuan Al Arif (2015b) dan Lutfiana \& Yulianto (2015). Pada kondisi ideal, Bank yang mampu menyalurkan lebih banyak pembiayaan dapat meningkatkan pendapatannya sekaligus meningkatkan tingkat efisiensinya (Muljawan, Hafidz, Astuti, \& Oktapiani, 2014). Gambar 1 di atas ini menjelaskan adanya interaksi positif antara FDR dengan ROA dimana peningkatan pembiayaan diikuti dengan peningkatan pendapatan bank syariah. Di sisi lain, terjadi interaksi yang tidak linear antara FDR dan ROA dengan BOPO yang seharusnya mampu semakin efisien seiring dengan peningkatan jumlah pembiayaan dan jumlah pendapatan. Hal ini dimungkinkan disebabkan oleh biaya-biaya besar yang harus ditransaksikan dengan kurangnya teknologi yang dikuasai oleh bank syariah dan besarnya biaya yang timbul saat proses spin-off.

Aspek makroekonomi juga berpotensi untuk mempengaruhi efisiensi perbankan. Hal ini tercermin dari ketatnya kebijakan makroprudensial untuk menjaga kondisi perekonomian tetap stabil. Temuan empiris dalam studi ini menjelaskan bahwa pertumbuhan ekonomi tidak memiliki dampak terhadap tingkat efisiensi perbankan syariah di Indonesia. Temuan ini mendukung studi Fernando \& Nimal (2014) Pambuko (2016), dan Sufian \& Habibullah (2010). Di sisi lain, studi ini tidak mendukung temuan Akhtar (2013) dan Sufian \& Noor (2009) yang menyatakan bahwa pertumbuhan ekonomi akan mendorong efisiensi bank. Pada umumnya, permintaan atas jasa keuangan cenderung tumbuh sebagai akibat dari pertumbuhan ekonomi dan peningkatan daya beli masyarakat. Namun pertumbuhan ekonomi Indonesia beberapa terakhir cenderung mengakibatkan penurunan permintaan atas jasa keuangan syariah, khususnya penyaluran pembiayaan dan peningkatan pembiayaan macet. Pada akhirnya, pertumbuhan ekonomi Indonesia belum mampu menjadi stimulus bagi peningkatan kinerja bank syariah, khususnya aspek efisiensi operasional.

\section{KESIMPULAN}

Studi ini dilakukan untuk menganalisis dampak kebijakan spinoff terhadap tingkat efisiensi perbankan syariah di Indonesia pada periode 2008-2018. Hasil penelitian menemukan bahwa kebijakan spin-off berpengaruh signifikan terhadap tingkat efisiensi. Ketika spinoff dilaksanakan, maka bank syariah akan beroperasi semakin efisien. Selanjutnya ROA juga berpengaruh signifikan dimana ketika pendapatan 
semakin besar maka bank syariah akan semakin efisien. Adapun variabel FDR dan pertumbuhan ekonomi tidak berpengaruh signifikan terhadap efisiensi perbankan syariah di Indonesia.

Simpulan di atas memiliki beberapa implikasi bagi perkembangan perbankan syariah di Indonesia. Pertama, unit syariah yang berencana untuk melakukan spin-off perlu melakukan forecasting terkait level efisiensi yang mungkin akan dicapai di masa mendatang. Jika hal tersebut masuk ke dalam rencana bisnis bank, maka OJK akan dengan mudah mengawal proses tersebut. Kedua, diperlukan formulasi kebijakan yang tepat dengan menciptakan produk perbankan syariah yang inovatif sehingga profitabilitas meningkat dan efisiensi tercapai. Kedua hal ini menjadi penting mengingat bahwa beberapa UUS tengah bersiap untuk melakukan spin-off, diantaranya adalah BPD Bank Sumut, BPD Bank Jatim dan BPD Bank Jateng.

\section{UCAPAN TERIMA KASIH}

Peneliti mengucapkan terima kasih kepada Universitas Muhammadiyah Magelang yang telah memfasilitasi penelitian ini melalui skema Penelitian Revitalisasi Visi Institusi (PRVI) tahun 2019.

\section{DAFTAR PUSTAKA}

Ahmad, N. H., \& Noor, M. A. N. M. (2010). The Determinants Efficiency and Profitability of World Islamic Banks. In International Conference on E-business, Management and Economics (hal. 228-233). Hongkong.

Akhtar, M. H. (2013). After the financial crisis: a cost efficiency analysis of banks from Saudi Arabia. International Journal of Islamic and Middle Eastern Finance and Management, 6(4), 322-332. https:// doi.org/10.1108/IMEFM-05-2013-0059

Al Arif, M. N. R. (2014). Spin-off and its impact on the third party funds of Indonesian Islamic banking industry. Economic journal of Emerging Markets, 6(1), 50-55.

Al Arif, M. N. R. (2015a). Impact of Spin-Off Policy on The Asset Growth on Indonesian Islamic Banking Industry. Journal of Islamic Economics, Banking and Finance, 11(4), 41-52. https://doi. org/10.12816/0024787

Al Arif, M. N. R. (2015b). Keterkaitan Kebijakan Pemisahan Terhadap Tingkat Efisiensi pada Industri Perbankan Syariah di Indonesia. Jurnal Keuangan dan Perbankan, 19(2), 295-304.

Al Arif, M. N. R. (2015c). The Effect of Spin-Off Policy on Financing Growth in Indonesian Islamic Banking Industry. Al-Ulum, 15(1), 173-184. 
Al Arif, M. N. R. (2017). Spin-Off and Market Share in the Indonesian Islamic Banking Industry: A Difference in Difference Analysis. Management and Marketing, 12(4), 540-551. https://doi. org/10.1515/mmcks-2017-0032

Al Arif, M. N. R. (2018). Does the Spin-Off Policy Can Accelerate the Deposit Funds in the Indonesian Islamic Banking Industry? Journal of Business and Retail Management Research, 13(1), 171-178.

Al Arif, M. N. R., \& Dewanti, E. P. (2017). Metode Spin-Off dan Tingkat Profitabilitas: Studi pada Bank Umum Syariah Hasil Spin-Off. Iqtishadia: Jurnal Kajian Ekonomi dan Bisnis Islam, 10(1), 23-43.

Al Arif, M. N. R., Haribowo, I., \& Suherlan, A. (2018). Spin-Off Policy and Efficiency in the Indonesian Islamic Banking Industry. Banks and Bank Systems, 13(1), 1-10. https://doi.org/10.21511/ bbs.13(1).2018.01

Al Arif, M. N. R., Nachrowi, N. D., Nasution, M. E., \& Mahmud, T. M. Z. (2017). The Islamic Banking Spin-Off: Lessons From Indonesian Islamic Banking Experiences. Journal of King Abdulaziz University, Islamic Economics, 30(2), 117-133. https://doi.org/10.4197/ Islec.30-2.11

Endri. (2008). Efisiensi Teknis Perbankan Syariah di Indonesia. Finance and Banking Journal, 10(2).

Fernando, J. M. R., \& Nimal, P. D. (2014). Does Risk Management Affect On Bank Efficiency? An Analysis of Sri Lankan Banking Sector. International Journal of Management and Sustainability, 3(2), 97-110.

Firdaus, M. F., \& Hosen, M. N. (2013). Efisiensi Bank Umum Syariah Menggunakan Pendekatan Two-Stage Data Envelopment Analysis. Bulletin Ekonomi Moneter dan Perbankan, 16(2), 167-188.

Hamid, A. (2015). The Impact of Spin-Off Policy to The Profitability on Indonesian Islamic Banking Industry. Al-Iqtishad: Jurnal Ilmu Ekonomi Syariah, VII(1), 117-126. https://doi.org/10.12816/0024787

Haribowo, I. (2017). The Indonesian Islamic Bank's Spin-off: A Study in Regional Development Banks. Al-Iqtishad: Journal of Islamic Economics, 9(1), 53-68. https://doi.org/10.15408/aiq.v9i1.4308

Haryanto, S. (2018). Determinan Efisiensi Bank: Analisis Bank Di Indonesia. Accounting and Financial Review, 1(1), 46-52.

Hilman, I. (2018). Sharia Business Unit Spin-off : Strategic Development Model of Sharia Banking in Indonesia. In The 5th IBSM International Conference on Business, Management and Accounting (hal. 856867). Hanoi: Hanoi University of Industry. https://doi.org/10.54655/ ijibfr.v2n2p1

Lutfiana, R. H., \& Yulianto, A. (2015). Determinan Tingkat Efisiensi Bank Umum Syaria di Indonesia (Pendekatan Two Stage DEA). 
Accounting Analysis Journal, 4(3), 1-10. https://doi.org/https:// doi.org/10.15294/aaj.v4i3.8313

Muljawan, D., Hafidz, J., Astuti, R. I., \& Oktapiani, R. (2014). Faktorfaktor Penentu Efisiensi Perbankan Indonesia Serta Dampaknya Terhadap Perhitungan Suku Bunga Kredit (No. WP/2/2014). Jakarta.

Nuryanto, \& Pambuko, Z. B. (2018). Eviews untuk Analisis Ekonometrika Dasar: Aplikasi dan Interpretasi. Magelang: Unimma Press.

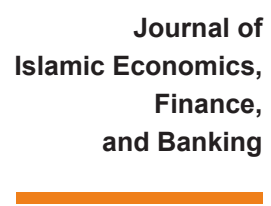

Vol. 2, No. 1, Juni 2019 , pp. 21-38, ISSN p:2622-4755 e:2622-4798

OJK. (2018). Sharia Banking Statistics December 2018. Jakarta. Diambil dari https://ojk.go.id/id/kanal/perbankan/data-danstatistik/statistik-perbankan-indonesia/Documents/Pages/StatistikPerbankan-Indonesia---Desember-2018/SPI Desember 2018.pdf

Pambuko, Z. B. (2016). Determinan Tingkat Efisiensi Perbankan Syariah di Indonesia : Two Stages Data Envelopment Analysis. Cakrawala: Jurnal Studi Islam, XI(2), 178-194. Diambil dari http://journal. ummgl.ac.id/index.php/cakrawala/article/view/249

Pambuko, Z. B., Ichsan, N., \& Anto, M. H. (2018). Islamic Banks' Financial Stability and Its Determinants: a Comparison Study With Conventional Banks in Indonesia. Iqtishadia: Jurnal Kajian Ekonomi dan Bisnis Islam, 11(2), 371-390. https://doi.org/10.21043/ iqtishadia.v11i2.3346

Pambuko, Z. B., Usman, N., \& Andriyani, L. (2019). Spin-off and Social Funds' Productivity of Islamic Banking Industry in Indonesia. In First International Conference on Progressive Civil Society (ICONPROCS 2019) (hal. 7-10). Atlantis Press. Diambil dari https://www.atlantispress.com/article/125908551

Poerwokoesoemo, A. (2016). Kinerja Bank Konvensional Pasca Spin Off Unit Usaha Syariah. Jurnal Keuangan dan Perbankan, 12(2), 145-164.

Purwanto. (2018). Fungsi Intermediary Bank Aceh Setelah Melakukan Konversi Menjadi Bank Umum Syariah. Ihtifaz: Journal of Islamic Economics, Finance, and Banking, 1(2), 137-145.

Putra, R. R., Syifadhiya, S., Widyastiti, S. A., \& Pambuko, Z. B. (2018). Efisiensi Perbankan Syariah di Indonesia dalam Mengelola Dana Sosial. In Proceedings of the 8th University Research Colloquium 2018 (hal. 224-228).

RI. Undang-undang Nomor 21 Tahun 2008 Tentang Perbankan Syariah (2008). Indonesia.

Sarifudin, M., \& Faturohman, T. (2017). Spin-Off Efficiency Analysis of Indonesian Islamic Banks. Journal of Business and Management, 6(2), 192-202.

Shidiqi, K. A., \& Rachmawati, A. (2018). Determinants of Sharia Banks' Efficiency In Indonesia: Panel Data Analysis. Jurnal Ekonomi Pembangunan: Kajian Masalah Ekonomi dan Pembangunan, 19(2), 186-195. https://doi.org/10.23917/jep.v19i2.6405 
Sihombing, N. H., \& Yahya, M. R. (2016). Pengaruh Kebijakan SpinOff, Beban Operasional Pendapatan Operasional (BOPO), Dana IHTIFAZ - JIEFB Pihak Ketiga (DPK), dan Non Performing Financing (NPF) Terhadap Profitabilitas Perbankan Syariah di Indonesia. Jurnal IImiah Mahasiswa Ekonomi Akuntansi, 1(2), 127-137.

Sufian, F. (2009). Determinants of bank efficiency during unstable macroeconomic environment: Empirical evidence from Malaysia. Research in International Business and Finance, 23(1), 54-77. https://doi.org/10.1016/j.ribaf.2008.07.002

Sufian, F., \& Habibullah, M. S. (2010). Bank-specific, Industry-specific and Macroeconomic Determinants of Bank Efficiency: Empirical Evidence from the Thai Banking Sector. Margin: The Journal of Applied Economic Research, 4(4), 427-461. https://doi. org/10.1177/097380101000400403

Sufian, F., \& Noor, M. A. N. M. (2009). The Determinants of Islamic Banks' Efficiency Changes Empirical Evidence from the MENA and Asian Banking Sectors. International Journal of Islamic and Middle Eastern Finance and Management, 2(2), 120-138. 